YIELD AND QUALITY OF GROUND WATER FROM STRATIFIED-DRIFT AQUIFERS, TAUNTON RIVER BASIN, MASSACHUSETTS: EXECUTIVE SUMMARY

By Wayne W. Lapham and Julio C. Olimpio

U.S. GEOLOGICAL SURVEY

Water-Resources Investigations Report 86-4053A

Prepared in cooperation with

COMMONWEALTH OF MASSACHUSETTS

DEPARTMENT OF ENVIRONMENTAL MANAGEMENT

DIVISION OF WATER RESOURCES

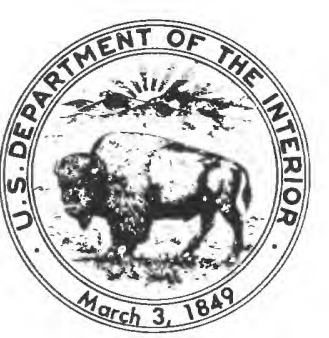




\section{DEPARTMENT OF THE INTERIOR}

MANUEL LUJAN, JR., Secretary

\section{U.S. GEOLOGICAL SUR VEY}

Dallas L. Peck, Director

\section{District Chief}

U.S. Geological Survey

Water Resources Division

10 Causeway Street, Suite 926

Boston, MA 02222-1040
Books and Open-File Reports Section

U.S. Geological Survey

Box 25425, Federal Center

Denver, CO 80225 


\section{CONTENTS}

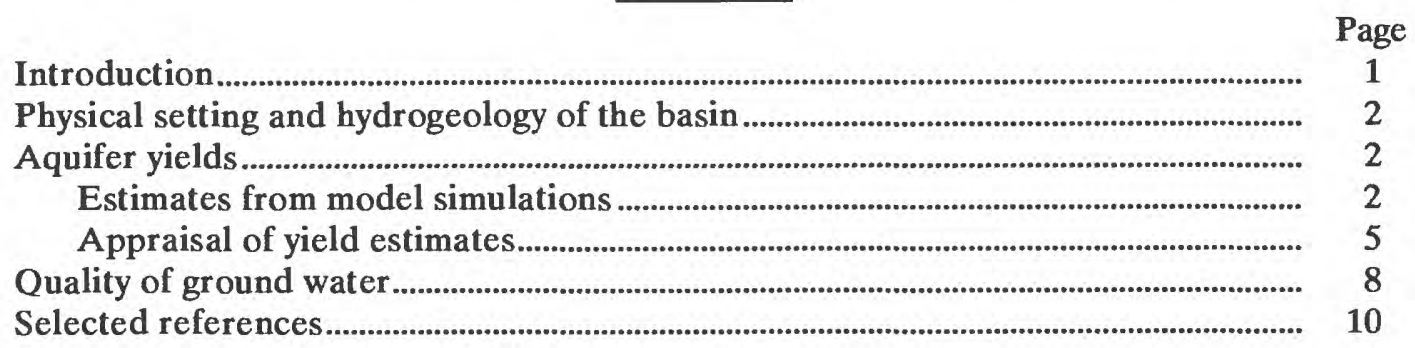

\section{ILLUSTRATIONS}

Figure 1. Map showing physical setting of the study area

2. Map showing names and locations of the 26 stratified-drift aquifers,

Taunton River basin, Massachusetts

\section{TABLES}

Table 1. Aquifer yields only from storage from the 26 aquifers

2. Aquifer yields available 90 percent of the time if minimum streamflow is maintained at 99.5-percent flow duration

3. Statistical summary of selected chemical constituent data in ground water in stratified-drift aquifers. 


\section{CONVERSION FACTORS AND ABBREVIATIONS}

For the convenience of readers who may prefer to use metric (International System) units rather than the inch-pound units used in this report, values may be converted by using the following factors.

Multiply inch-pound unit

By

To obtain metric unit

\begin{tabular}{|c|c|c|}
\hline & Length & \\
\hline inch (in.) & 25.4 & millimeter $(\mathrm{mm})$ \\
\hline foot (ft) & 0.3048 & meter $(\mathrm{m})$ \\
\hline \multirow[t]{2}{*}{ mile (mi) } & 1.609 & kilometer (km) \\
\hline & Area & \\
\hline \multirow[t]{2}{*}{ square mile $\left(\mathrm{mi}^{2}\right)$} & 2.590 & square kilometer $\left(\mathrm{km}^{2}\right)$ \\
\hline & $\underline{\text { Flow }}$ & \\
\hline cubic foot per second $\left(\mathrm{ft}^{3} / \mathrm{s}\right)$ & 0.02832 & $\begin{array}{l}\text { cubic meter per second } \\
\left(\mathrm{m}^{3} / \mathrm{s}\right)\end{array}$ \\
\hline $\begin{array}{l}\text { cubic foot per second per } \\
\text { square mile }\left[\left(\mathrm{ft}^{3} / \mathrm{s}\right) / \mathrm{mi}^{2}\right]\end{array}$ & 0.01093 & $\begin{array}{l}\text { cubic meter per second } \\
\text { per square kilometer } \\
{\left[\left(\mathrm{m}^{3} / \mathrm{s}\right) / \mathrm{km}^{2}\right]}\end{array}$ \\
\hline
\end{tabular}

Hydraulic conductivity

foot per day (ft/d)

0.3048

meter per day $(\mathrm{m} / \mathrm{d})$

Transmissivity

square foot per day $\left(\mathrm{ft}^{2} / \mathrm{d}\right)$

square meter per day $\left(\mathrm{m}^{2} / \mathrm{d}\right)$

Temperature

Temperature in degrees Fahrenheit $\left({ }^{\circ} \mathrm{F}\right)$ can be converted to degrees Celsius $\left({ }^{\circ} \mathrm{C}\right)$ as follows: ${ }^{\circ} \mathrm{C}=5 / 9\left({ }^{\circ} \mathrm{F}-32\right)$.

Sea level: In this report "sea level" refers to the National Geodetic Vertical Datum of 1929 (NGVD of 1929)--a geodetic datum derived from a general adjustment of the first-order level nets of both the United States and Canada, formerly called "Mean Sea Level of 1929." 


\title{
Yield and Quality of Ground Water from Stratified-Drift Aquifers, Taunton River Basin, Massachusetts:
}

\author{
EXECUTIVE SUMMARY
}

\author{
By Wayne W. Lapham and Julio C. Olimpio
}

\section{INTRODUCTION}

Water shortages are a chronic problem in parts of the Taunton River basin and are caused by a combination of factors. One factor is that groundvater resources are limited, particularly in the northern half of the basin where glacial stratifieddrift aquifers, which are the only sources used for public-water supply, are thin, small, and discontinuous. A second factor is drought or at least unusually dry conditions, which have occurred several times in the last 25 years and have caused water levels in aquifers to decline; this results in mandatory reductions in pumping rates. A third factor is that overall water use in the basin has increased during the past several decades. Finally, perhaps the most important factor is conjunctive water use in the basin. Withdrawal of water from surface-water and ground-water municipal-supply sources that are hydraulically connected affects the amount of yield from each source, and the yield available from similar water supplies elsewhere in the basin.

Water use in this part of the Boston metropolitan area is likely to increase during the next decade. Therefore, water shortages are predicted to become more widespread and to occur more frequently. The Massachusetts Division of
Water Resources projects that about 50 percent of the cities and towns within and on the perimeter of the basin may have water-supply deficits by 1990 , if water-management projects are not pursued throughout the 1980's.

In a recent report, Lapham (1988) presents a thorough technical discussion of the (1) hydrogeologic characteristics of the Taunton River basin, with focus on the northern half of the basin; (2) estimation of aquifer yields from 26 selected stratified-drift aquifers; (3) assessment of the potential yield of aquifers to support new development; and (4) description of the quality of ground water in the basin. The Taunton River basin study was done cooperatively by the U.S. Geological Survey and the Massachusetts Department of Environmental Management, Division of Water Resources, and is one of several studies under Chapter 800 Massachusetts legislation, which enables quantitative assessments of regional ground-water resources in the State.

This report summarizes the results of the Taunton River basin hydrogeologic study and provides a nontechnical description of the hydrologic and geologic characteristics of the basin, a discussion of the yields of the stratified-drift aquifers as determined from model simulation, and a discussion of the ground-water quality in the basin. 


\section{PHYSICAL SETTING AND HYDROGEOLOGY OF THE BASIN}

The Taunton River basin covers $530 \mathrm{mi}^{2}$ (square miles) of Bristol, Norfolk, and Plymouth Counties in southeastern Massachusetts. All or parts of the cities of Attleboro, Brockton, Fall River, New Bedford, and Taunton, and 36 towns are in the basin (fig. 1). The basin is drained by the Matfield, Town, and Taunton Rivers.

Tributary streams include the Canoe, Nemasket, Wading, Threemile, and Winnetuxet Rivers. Surface-water drainage is generally southward toward Mount Hope Bay, a part of Narragansett Bay at Fall River.

Stratified-drift deposits cover about 62 percent of the basin. These deposits are primarily ice-contact, outwash, and lake-bottom sediments, which were deposited in preglacial bedrock valleys and in water-filled depressions in the till and bedrock surface during retreat of the last glacier. The sediments are composed of sand, gravel, cobbles, silt, and clay. The drift ranges in thickness from zero to about 200 $\mathrm{ft}$ (feet) in some of the deep preglacial bedrock valleys. The thickest deposits are lake-bottom deposits composed of fine sand interbedded with silt and clay. Stratified-drift deposits are more abundant in the central and southern parts of the basin than in the northern part of the basin. In the northern onethird of the basin, stratified drift fills narrow, northsouth trending valleys, which are bordered by till and bedrock uplands.

Yields of wells in the fine-grained stratifieddrift deposits are usually no more than a few gallons per minute ( $\mathrm{gal} / \mathrm{min}$ ) whereas yields of wells in the coarse-grained stratified drift may exceed 300 $\mathrm{gal} / \mathrm{min}$. The coarse-grained parts of the stratifieddrift deposits form the major aquifers in the basin. In the northern part of the basin, these aquifers are long, narrow, and thin, and have saturated thicknesses that range from about $20 \mathrm{ft}$ to somewhat more than $100 \mathrm{ft}$. The widths of the stratified-drift aquifers generally range from 0.1 to $1.5 \mathrm{mi}$ (miles), and their lengths generally range from 1 to $5 \mathrm{mi}$.

Twenty-six stratified-drift aquifers in the northern half of the basin were studied in detail (fig. 2). These aquifers were selected because current and projected 1990 water-supply deficits are greatest in the northern half of the basin, affecting 14 of 19 municipalities. In contrast, only one of nine municipalities in the southern half of the basin is projected to have a deficit (Richard Thibedeau, Massachusetts Division of Water Resources, written commun.,1984). The 26 aquifers also were selected because the use of ground water as the sole source of supply is greatest in the northern half of the basin. Fifteen of 19 municipalities in the northern half of the basin use ground water as compared to 4 of 9 municipalities in the southern half of the basin.

The 26 stratified-drift aquifers were identified as areas of stratified drift that have a transmissivity equal to or greater than $1,337 \mathrm{ft}^{2} / \mathrm{d}$ (square feet per day), which is equivalent to 10,000 gallons per day per foot. The aquifers underlie or are near major rivers or tributaries. The aquifers are composed mostly of layers of sand and gravel but include some interbedded layers of silt and clay. John R. Williams (U.S. Geological Survey, written commun., 1982) determined that the hydraulic conductivity of fineto-coarse gravel ranges from about 150 to $500 \mathrm{ft} / \mathrm{d}$ (feet per day), mixed sand and gravel averages about $200 \mathrm{ft} / \mathrm{d}$, and fine-to-coarse sand ranges from about 25 to $150 \mathrm{ft} / \mathrm{d}$. The transmissivity of the stratified drift is equal to the product of its hydraulic conductivity and saturated thickness. Therefore, equal transmissivities at different locations in an aquifer may be the result of thin deposits of high-conductivity drift or thick deposits of low-conductivity drift. Transmissivity exceeds $4,000 \mathrm{ft}^{2} / \mathrm{d}$ in small areas in nearly all 26 aquifers. In a few areas, where the stratified drift is thick or has a high hydraulic conductivity, transmissivity exceeds $10,000 \mathrm{ft}^{2} / \mathrm{d}$.

\section{AQUIFER YIELDS}

\section{Estimates from Model Simulations}

During severe drought, ground-water discharge from aquifers to streams is reduced or ceases, streamflow is at a minimum, and only small amounts of surface water are stored in wetlands and ponds. Consequently, water pumped from most aquifers in New England during severe drought is derived largely from storage in the aquifers. During normal climatic conditions, water pumped from an aquifer is derived from storage, intercepted ground-water discharge, and induced infiltration of surface water. To account for drought and normal conditions, two sets of aquifer-yield estimates were made for each of the 26 stratified-drift aquifers using simple groundwater flow models. "Short-term" aquifer yields during drought conditions were determined by considering only water from storage and are expressed as single values for several selected pumping periods. "Long-term" aquifer yields during normal 


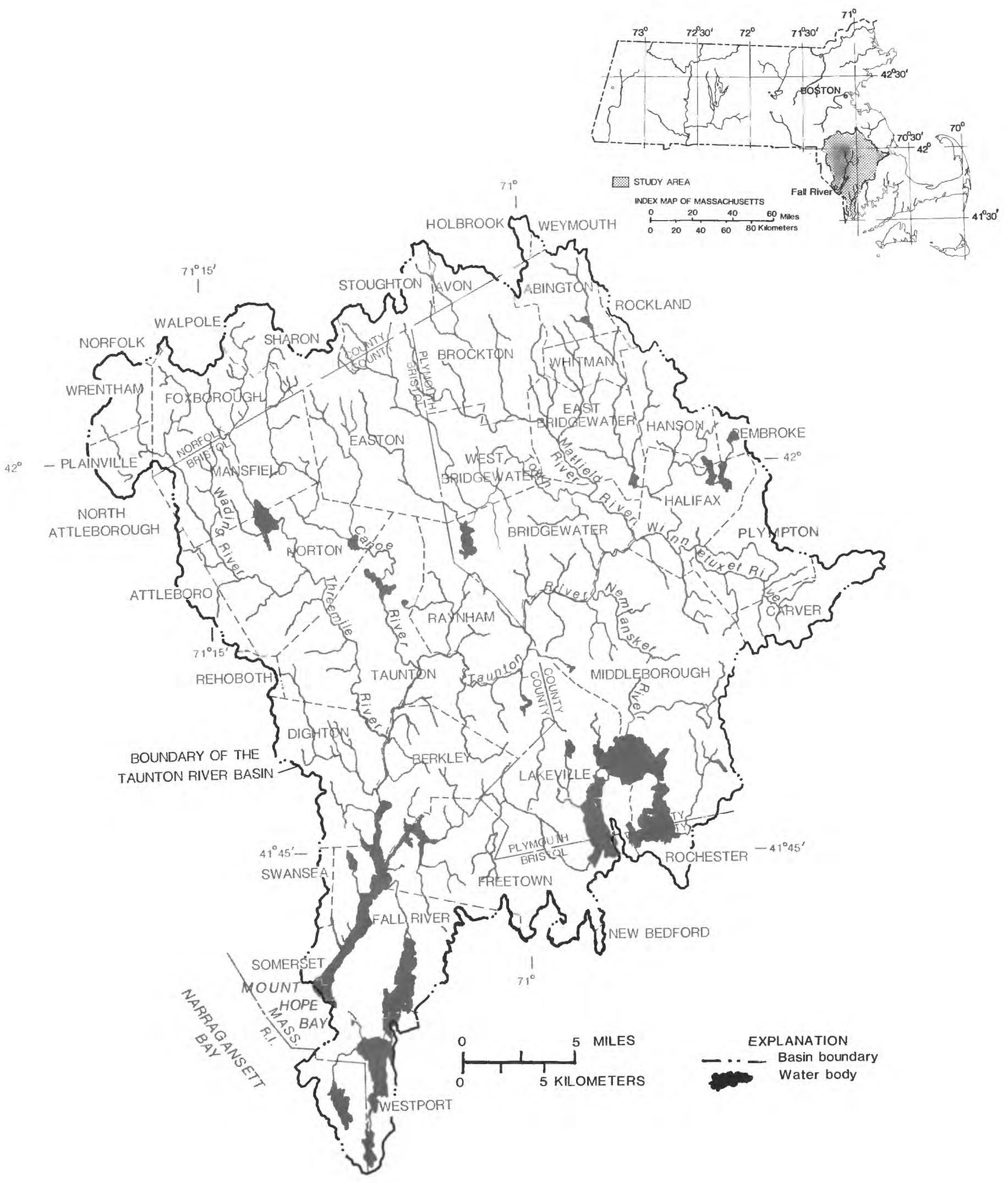

Figure 1.--Physical setting of the study area. 


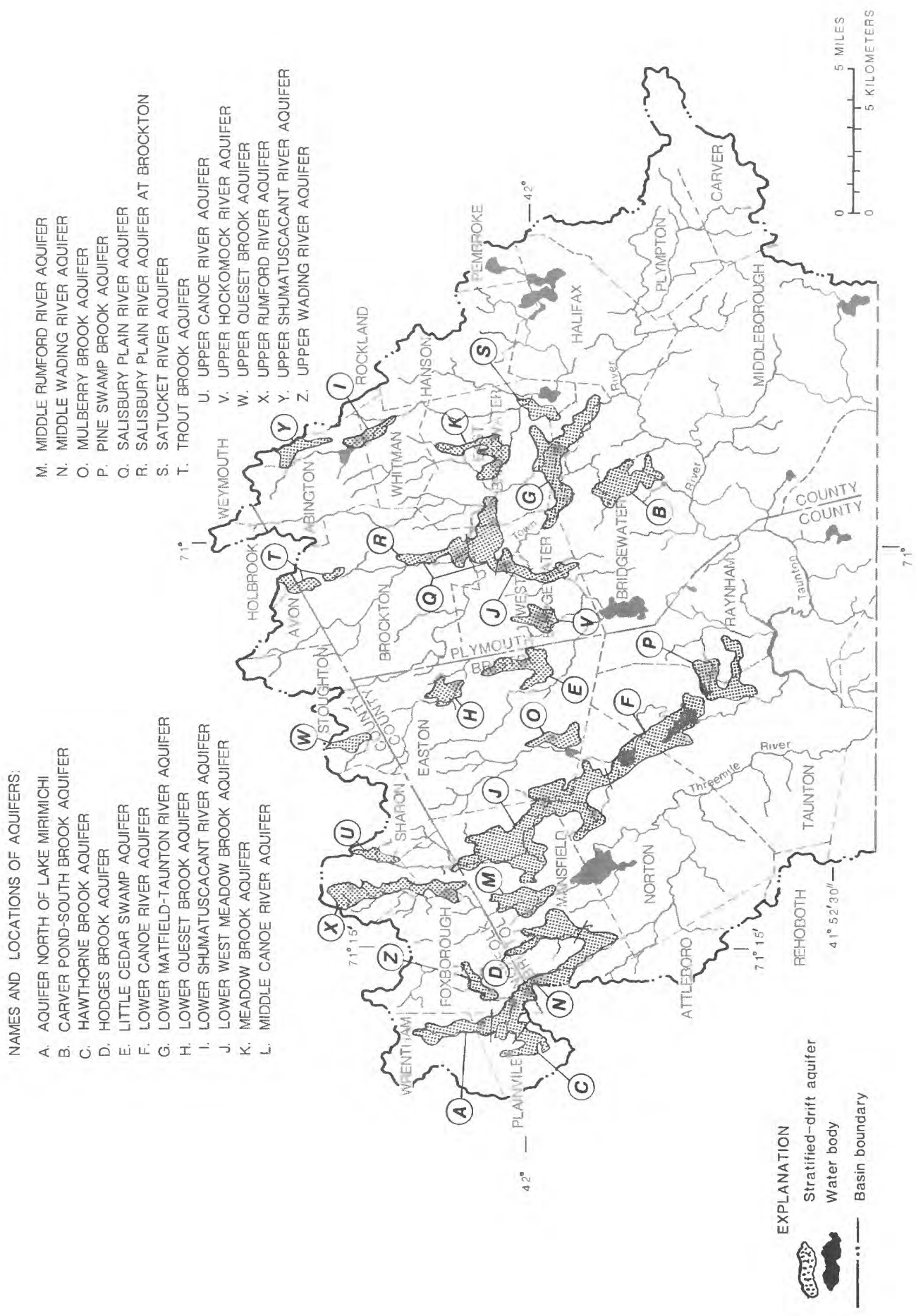

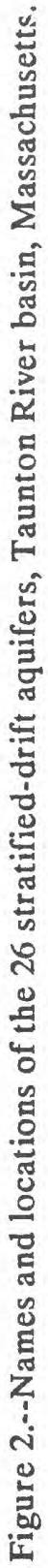


climatic conditions were determined by considering water available from storage, intercepted groundwater discharge, and induced infiltration, and are expressed in terms of exceedance values for available streamflow.

On the basis of estimates of the short-term yields of the 26 aquifers (table 1), yields for a 30-day pumping period range from 2.6 to $15.0 \mathrm{ft}^{3} / \mathrm{s}$ (cubic feet per second) $\left(1 \mathrm{ft}^{3} / \mathrm{s}=0.646 \mathrm{Mgal} / \mathrm{d}\right.$ (million gallons per day)). Fourteen of the 26 aquifers have yields less than $5 \mathrm{ft}^{3} / \mathrm{s}, 7$ have yields that range from 5 to $10 \mathrm{ft}^{3} / \mathrm{s}$, and five have yields between $10 \mathrm{ft}^{3} / \mathrm{s}$ and $15 \mathrm{ft}^{3} / \mathrm{s}$. For a 180 -day pumping period, short-term yields of the 26 aquifers range from 1.6 to $10.5 \mathrm{ft}^{3} / \mathrm{s}$. Nineteen of the 26 aquifers have yields less than 5 $\mathrm{ft}^{3} / \mathrm{s}$, six have yields that range from 5 to $10 \mathrm{ft}^{3} / \mathrm{s}$, and one has a yield of $10.5 \mathrm{ft}^{3} / \mathrm{s}$. The estimates of yields from aquifer storage are applicable during severe drought. Because water is derived primarily from storage during severe drought, steady-state conditions may not be achieved, and continued pumping may cause continued water-level declines.

On the basis of the aquifer-yield data in table 1 , one might conclude that large amounts of water are available in the 26 stratified-drift aquifers. However, rates given in table 1 are short-term yields. Potential long-term yields may be less than these short-term yields and are not constant over time, because streamflow, which varies seasonally, is an important source of water contributing to long-term yield. Therefore, the long-term yield estimate of each aquifer depends partly on the amount of streamflow that is to be maintained in the streams flowing over each aquifer. Estimated yields of the 26 aquifers available 90 percent of the time when streamflow of the major stream that drains each aquifer equals or exceeds the 99.5-percent duration of flow are presented in table 2. The aquifer yield, and, for comparison purposes, the 1983 pumping rate for each aquifer are presented in the table.

Estimates of the long-term yield of the 26 aquifers (table 2) indicate that the yields of the two most productive aquifers equal or exceed 11.9 and $11.3 \mathrm{ft}^{3} / \mathrm{s} 90$ percent of the time, respectively, if minimum stream discharge is maintained at 99.5 -percent flow duration. Eighteen of the 26 aquifers were pumped for public-water supply during 1983 . Further analysis of the yield characteristics of these 18 aquifers indicates that the 1983 pumping rate of each of these 18 aquifers can be sustained at least 70 percent of the time.

\section{Appraisal of Yield Estimates}

The yields of aquifers estimated in this study are based on all available information about the geometry and hydraulic properties of the aquifers. The yield estimates are the results of model simulations assuming conditions that existed prior to any aquifer development and that represent the entire area of the aquifer. Actual yields may differ from the estimated yields because of specific limitations in well-field design or well performance. For example, a location where yield of an aquifer is greatest may not be suitable for development because the quality of the water is unacceptable, or it may be physically or economically more feasible to locate a well field elsewhere. In addition, well efficiency is less than 100 percent, although efficiency was assumed to be 100 percent for the estimates of aquifer yields. Also, 100 percent of the groundwater discharge from the aquifer is not captured by pumping; rather, only a fraction of the ground-water discharge may be captured by wells.

Estimates of aquifer yields listed in table 2 were based on the assumption that water is derived only from three sources--intercepted ground-water discharge, induced infiltration, and storage. However, other sources of water can increase actual yields, and these sources may be important in some areas of the basin. Four additional sources of water are: (1) ground-water discharge from the aquifer across subbasin boundaries as underflow, which could be captured by pumping prior to discharging; (2) water conserved by lowering the water table, which reduces evapotranspiration of ground water; (3) return flow from wastewater discharge; and (4) water available from storage during conditions when streamflow is not available for induced infiltration.

Underflow was not considered as a source of water for the yield estimates because the hydrogeologic characteristics of the northern half of the Taunton River basin are such that rates of underflow from adjacent subbasins probably are small compared to rates available from the three sources considered in this study. Water conserved by reduction of evapotranspiration and water captured as return flows from wastewater discharge may be important, but these sources were not added to the yield estimates because the extensive collection and analysis of the data required for such calculations were beyond the scope of this study. Nevertheless, future determinations of aquifer yields in small, highly developed areas might benefit from inclusion of that information. Water derived from storage during 
Table 1.--Aquifer yields only from storage from the 26 aquifers

Aquifer system and aquifer name
Aquifer yield, in cubic feet per second ${ }^{1}$, for indicated pumping period, in days

Pumping period

\section{0}

3.4

10.1

3.8

15.0

Upper Hocomock River

Rumford River aquifer system

Upper Rumford River

Middle Rumford River

Salisbury River aquifer system

Trout Brook

Salisbury Plain River in Brockton

Salisbury Plain River

Satucket River aquifer system

Upper Shumatuscacant River

Lower Shumatuscacant River

Satucket River

Wading River aquifer system

Upper Wading River

Aquifer north of Lake Mirimichi

Hawthorne Brook

Middle Wading River

Hodges Brook

5.7

3.7

7.1

3.7

9.8

3.4

4.6

3.0

Other aquifers

Carver Pond-South Brook

Little Cedar Swamp

Lower Matfield-Taunton River

Lower West Meadow Brook

Meadow Brook

Pine Swamp Brook

60

180

365

1.0

5.7

1.6

$\begin{array}{rrr}3.2 & 1.2 & 8.3 \\ 13.7 & 10.5 & 8.6\end{array}$

2.8

3.3

4.1

1.8

1.2

1.5

2.2

3.0

3.5

2.6

5.0

3.1

2.0

1.4

6.6

\section{8}

1.8

1.5

3.6

2.3

1.7

${ }^{1} 1 \mathrm{ft}^{3} / \mathrm{s}=0.646 \mathrm{Mgal} / \mathrm{d}$. 
Table 2.- Aquifer yields available 90 percent of the time if minimum streamflow is maintained at 99.5-percent flow duration

[All aquifer yields and pumping rates are given in cubic feet per second; the number to the left of the slash is the rate with no development of upstream aquifers; the number following the slash is the rate with full development of upstream aquifers]

Aquifer system and aquifer name

Aquifer yield $^{1}$

1983 pumping rate ${ }^{2}$

Canoe River aquifer system

Upper Canoe River

$2.8 / 2.4$

0.3

Middle Canoe River

1.5

3.9

Mulberry Brook

$11.3 / 6.0$

.0

Lower Canoe River

1.9

Hockomock River aquifer system

Upper Queset Brook

Lower Queset Brook

Upper Hockomock River

Rumford River aquifer system

Upper Rumford River

Middle Rumford River

Salisbury River aquifer system

Trout Brook

Salisbury Plain River

in Brockton

1.8/1.2

.2

Salisbury Plain River

Satucket River aquifer system

Upper Shumatuscacant River

Lower Shumatuscacant River

Satucket River

Wading River aquifer system

Upper Wading River

$.4 \quad 2$

Aquifer north of Lake Mirimichi

Hawthorne Brook

Middle Wading River

Hodges Brook

Other aquifers

Carver Pond-South Brook

$\begin{array}{rr}.4 & .5 \\ .8 & .0 \\ 11.9 & .8 \\ 2.5 & .0 \\ 1.0 & .0 \\ .1 & .0\end{array}$

1 Aquifer yield equaled or exceeded 90 percent of the time.

${ }^{2}$ Richard Thibedeau, Massachusetts Division of Water Resources, written commun., 1983. 
pumping when no stream discharge is available for infiltration was not considered in the study because the areal extent and thickness of the 26 aquifers are small. Therefore, the additional water derived from storage probably would be small.

Four management options were selected to illustrate how estimates of aquifer yield could vary depending on maintained minimum streamflows. The four management options were: 1) aquifer yields available 70 percent of the time if minimum streamflow is maintained at the 99.5-percent flow duration; (2) aquifer yields available 70 percent of the time if minimum streamflow is maintained at the 95-percent flow duration; (3) aquifer yields available 90 percent of the time if minimum streamflow is maintained at the 99.5-percent flow duration; and (4) aquifer yields available 90 percent of the time if minimum streamflow is maintained at the 95 -percent flow duration. Comparison of the estimated yields of the aquifers with the 1983 pumping rates indicates that the yields of most aquifers equal or exceed the 1983 pumping rates, under all selected flow conditions. However, several aquifers were pumped in 1983 at rates that exceed the estimated yields available under the two most restrictive management options (options 3 and 4 above). Therefore, under the two most restrictive management options, some percentage of the time these aquifers cannot yield water to wells at the 1983 pumping rate unless stream discharge decreases below the minimum flow conditions assumed for those two management options.

The aquifer yield estimates in tables 1 and 2 may be useful in (1) assessing the potential of an aquifer to sustain current and future withdrawals during normal and drought conditions, (2) planning and managing the regional development of the water resources for all uses in the basin, and (3) assessing the need for and effects of interbasin and intrabasin transfer of water.

\section{QUALITY OF GROUND WATER}

Selected physical properties and concentrations of major chemical constituents in ground water from the stratified-drift aquifers at 80 sampling sites were used to characterize general water quality in aquifers throughout the basin. Results of the analyses are listed in table 3 .

The $\mathrm{pH}$ of the ground water ranged from 5.4 to 7.0. At half of the sampling sites, $\mathrm{pH}$ was less than 6.0 , and at 90 percent of the sites, $\mathrm{pH}$ was less than 6.5. As a result, this water is considered acidic and is capable of corroding pipes and plumbing fixtures.
Hardness of the ground water ranged from 9 to 97 $\mathrm{mg} / \mathrm{L}$ (milligrams per liter as $\mathrm{CaCO}_{3}$ ). At 86 percent of the sites, hardness was less than or equal to 60 $\mathrm{mg} / \mathrm{L}$, which classifies the ground water at these sites as soft (Durfor and Becker, 1964). No concentrations of sulfate or chloride that exceeded Massachusetts limits recommended for drinking water were found in the ground water (Massachusetts Department of Environmental Quality Engineering, 1982). However, concentrations of sodium in 19 samples exceeded the limit of $20 \mathrm{mg} / \mathrm{L}$ recommended by Massachusetts for drinking water for those individuals on a sodium-restricted diet (Massachusetts Department of Environmental Quality Engineering, 1982).

Natural elevated concentrations of iron and manganese in water in the stratified-drift aquifers are present locally in the basin. Natural concentrations of these two metals commonly exceed the limits of $0.3 \mathrm{mg} / \mathrm{L}$ for iron and $0.05 \mathrm{mg} / \mathrm{L}$ for manganese recommended for drinking water (U.S. Environmental Protection Agency, 1980). Twelve of the 80 samples analyzed for iron and 37 of the 80 samples analyzed for manganese had concentrations that exceeded the recommended limits.

Fifty-one analyses of selected trace metals in ground-water samples (arsenic, barium, cadmium, chromium, copper, cyanide, lead, mercury, selenium, silver, zinc, and nickel) from stratifieddrift aquifers throughout the basin were used to characterize trace metal concentrations in the ground water. Of the 10 constituents sampled that have U.S. Environmental Protection Agency limits recommended for drinking water, only the lead concentration in water at one site $((60 \mu \mathrm{g} / \mathrm{L})$ (micrograms per liter)) exceeded the recommended limit of $50 \mu \mathrm{g} / \mathrm{L}$.

Analyses of selected organic compounds in water in the stratified-drift aquifers at 74 locations revealed that 13 of the samples contained one or more of the following compounds: chloroform; carbon tetrachloride; 1,1 dichloroethane; 1,2 transdichloroethylene; tetrachloroethylene; toluene; 1,1,1 trichloroethane; and trichloroethylene.

The U.S. Environmental Protection Agency has set maximum contaminant levels (MCLs) for community water systems for eight synthetic organic compounds (U.S. Environmental Protection Agency, 1985). These eight compounds and their MCLs are: trichloroethylene, $5 \mu \mathrm{g} / \mathrm{L}$; carbon tetrachloride, $5 \mu \mathrm{g} / \mathrm{L}$; vinyl chloride, $1 \mu \mathrm{g} / \mathrm{L}$; 1,2 -dichloroethane, 5 $\mu \mathrm{g} / \mathrm{L}$; benzene, $5 \mu \mathrm{g} / \mathrm{L} ; 1,1$-dichloroethylene, $7 \mu \mathrm{g} / \mathrm{L}$; 1,1,1-trichloroethane, $200 \mu \mathrm{g} / \mathrm{L}$; and p-dichlorobenzene, $750 \mu \mathrm{g} / \mathrm{L}$. As noted above, three of these com- 
Table 3.--Statistical summary of selected chemical constituent data in ground water in stratified-drift aquifers

[Data are in milligrams per liter except as indicated; dashes indicate not applicable]

\begin{tabular}{|c|c|c|c|c|c|c|c|c|}
\hline \multirow[b]{2}{*}{$\begin{array}{c}\text { Constituents } \\
\text { and } \\
\text { properties }\end{array}$} & \multirow[b]{2}{*}{$\begin{array}{c}\text { Number } \\
\text { of } \\
\text { analyses }\end{array}$} & \multicolumn{7}{|c|}{ Concentration } \\
\hline & & $\begin{array}{l}\text { Recom- } \\
\text { mended } \\
\text { limit }^{1}\end{array}$ & $\begin{array}{l}\text { Minimum } \\
\text { value }\end{array}$ & Mean & $\begin{array}{c}\text { Maximum } \\
\text { value }\end{array}$ & $\begin{array}{c}\text { Values in } \\
50 \text { percent } \\
\text { of } \\
\text { analyses } \\
\text { are less } \\
\text { than those } \\
\text { shown }\end{array}$ & $\begin{array}{l}\text { Values in } \\
90 \text { percent } \\
\text { of } \\
\text { analyses } \\
\text { are less } \\
\text { than those } \\
\text { shown }\end{array}$ & $\begin{array}{l}\text { Number } \\
\text { of } \\
\text { samples } \\
\text { exceeding } \\
\text { recom- } \\
\text { mended } \\
\text { limit }\end{array}$ \\
\hline pH (units) & 79 & - & 5.4 & -- & 7.0 & 6.0 & 6.5 & - \\
\hline Alkalinity & & & & & & & & \\
\hline$\left(\right.$ as $\left.\mathrm{CaCO}_{3}\right)$ & 80 & - & 4.0 & 16.5 & 41.0 & 14.5 & 27.0 & -- \\
\hline $\begin{array}{l}\text { Hardness } \\
\qquad(\mathrm{Ca}+\mathrm{Mg} \\
\left.\quad \text { as } \mathrm{CaCO}_{3}\right)\end{array}$ & & ${ }^{2}-$ & & & & & & \\
\hline Calcium & 80 & -- & $\begin{array}{l}9.0 \\
1.6\end{array}$ & $\begin{array}{l}37.3 \\
10.0\end{array}$ & $\begin{array}{l}97.0 \\
25.0\end{array}$ & $\begin{array}{r}34.5 \\
9.1\end{array}$ & $\begin{array}{l}69.2 \\
17.0\end{array}$ & $\begin{array}{l}0 \\
--\end{array}$ \\
\hline Magnesium & 80 & - & .9 & 3.1 & 21.0 & 2.3 & 5.9 & -- \\
\hline Sodium & 80 & ${ }^{3} 20$ & 2.0 & 15.7 & 54.0 & 11.3 & 30.0 & 19 \\
\hline Potassium & 80 & -- & .3 & 1.4 & 8.6 & 1.0 & 2.3 & - \\
\hline Iron & 80 & .3 & .0 & .6 & 19.0 & .02 & .57 & 12 \\
\hline Manganese & 80 & .05 & .0 & .2 & 2.1 & .02 & .62 & 37 \\
\hline Sulfate & 80 & 250 & 2.0 & 16.7 & 44.0 & 14.9 & 33.0 & 0 \\
\hline Chloride & 80 & 250 & 4.0 & 23.6 & 87.0 & 18.5 & 55.0 & 0 \\
\hline Nitrate (as N) & 80 & 10 & .0 & 1.4 & 16.0 & .82 & 2.7 & 2 \\
\hline $\begin{array}{l}\text { Specific } \\
\text { conductance } \\
\text { (microsie- } \\
\text { mens per } \\
\text { centimeter } \\
\text { at } 25^{\circ} \mathrm{C} \text { ) }\end{array}$ & 80 & -- & 38.0 & 161 & 410 & 142 & 280 & -- \\
\hline
\end{tabular}

${ }^{1}$ Recommended limits for drinking water, U.S. Environmental Protection Agency (1975; 1977;1980).

${ }^{2}$ Soft water is commonly considered to have hardness concentrations between 0 and $60 \mathrm{mg} / \mathrm{L}$ (Durfor and Becker, 1964).

${ }^{3}$ Recommended limit for drinking water for those individuals on sodium-restricted diets (MDEQE, 1982). 
pounds were detected. Trichloroethylene was detected in five samples. The concentration of trichloroethylene in one of these five samples exceeded the limit of $5 \mu \mathrm{g} / \mathrm{L}$. A concentration of carbon tetrachloride of $0.8 \mu \mathrm{g} / \mathrm{L}$ was detected in one sample, which is below the MCL of $5 \mu \mathrm{g} / \mathrm{L}$. Concentrations of 1,1,1 trichloroethane were detected in 10 samples, but none exceeded the MCL for that compound.

\section{SELECTED REFERENCES}

Allen, W. B., Hahn, G. W., and Brackley, R. A., 1966, Availability of groundwater, upper Pawcatuck River basin, Rhode Island: U.S. Geological Survey Water-Supply Paper 1821, $66 \mathrm{p}$.

Camp, Dresser, and McKee, 1965, Report on water resources of Bristol and Plymouth Counties: Report to Commonwealth of Massachusetts, Water Resources Commission, $14 \mathrm{p}$.

Durfor, C. N., and Becker, Edith, 1964, Public water supplies of the 100 largest cities in the United States, 1962: U.S. Geological Survey WaterSupply Paper 1812, 364 p.

Fenneman, N. M., 1938, Physiography of eastern United States: New York, McGraw-Hill, 714 p.

Frimpter, M. H,, 1973a, Ground-water management, Taunton River basin, Massachusetts: U.S. Geological Survey Open-File Report, section 3.03 .

1973b, Preliminary single-purpose report, ground-water hydrology, southeastern New England: U.S. Geological Survey Open-File Report, section 2.01, 17 p.

Frimpter, M. H., and Gay, F. B., 1979, Chemical quality of ground water on Cape Cod, Mass.: U.S. Geological Survey Water-Resources Investigations Report 79-65, 11 p.

Frimpter, M. H., and Maevsky, Anthony, 1979, Geohydrologic impacts of coal development in the Narragansett basin, Massachusetts and Rhode Island: U.S. Geological Survey WaterSupply Paper 2062, 35 p.

Gonthier, J. B., Johnston, H. E., and Malmberg, G. T., 1974, Availability of ground water in the lower Pawcatuck River basin, Rhode Island: U.S. Geological Survey Water-Supply Paper 2033, 40 p.
Haeni, F. P., 1978, Computer modeling of groundwater availability in the Pootatuck River valley, Newtown, Connecticut: U.S. Geological Survey Water-Resources Investigations Report 78-77, $65 \mathrm{p}$.

Johnson, A. I., 1967, Specific yield--compilation of specific yields for various materials: U.S. Geological Survey Water-Supply Paper 1622-D, $74 \mathrm{p}$.

Johnston, H. E., and Dickerman, D. C., 1974, Availability of ground water in the Branch River basin, Providence County, Rhode Island: U.S. Geological Survey Water-Resources Investigations Report 18-74, 39 p.

Lapham, W. W., 1988, Yield and quality of ground water from stratified-drift aquifers, Taunton River basin, Massachusetts: U.S. Geological Survey Water-Resources Investigations Report 86-4053, 69 p.

LaSala, A. M., Jr., 1968, Ground-water resources of the Erie-Niagara basin, New York: ErieNiagara Basin Regional Water Resources Planning Board Report ENB-3, 113 p.

Maevsky, Anthony, 1976, Ground-water levels in Massachusetts, 1936-74: U.S. Geological Survey Open-File Report, Massachusetts Hydrologic-Data Report No. 17, 107 p.

Massachusetts Department of Environmental Quality Engineering, 1982, Drinking Water: 310 CMR, 22.06, v. 12, p. 332-336.

Massachusetts Water Resources Commission, 1983, Water management projects of communities with projected 1990 water deficits: Massachusetts Department of Environmental Management, Division of Water Resources, River Basin Planning Program.

McDonald, M. G., and Harbaugh, A. W., 1984, A modular three-dimensional finite-difference ground-water flow model: U.S. Geological Survey Open-File Report 83-875, 528 p.

New England River Basins Commission, 1975, Report of the southeastern New England study Taunton planning area report, no. 6 .

Old Colony Planning Council, 1977, Ground-water resources of the Old Colony Planning Council 208 area: Old Colony Planning Council, Brockton, Mass., 59 p. 
Olimpio, J. C., and de Lima, Virginia, 1984, Groundwater resources of the Mattapoisett River valley aquifer, Plymouth County, Massachusetts: U.S. Geological Survey Water-Resources Investigations Report 84-4043, 83 p.

Pollock, S. J., and Toler, L. G., 1973, Effects of highway de-icing salts on groundwater and water supplies in Massachusetts: Highway Research Record, No. 425, Environmental Degradation by De-Icing Chemicals and Effective Countermeasures, p. 17-22.

Rosenshein, J. S., Gonthier, J. B., and Allen, W. B., 1968, Hydrologic characteristics and sustained yield of principal ground-water units Potowomut-Wickford area, Rhode Island: U.S. Geological Survey Water-Supply Paper 1775, $38 \mathrm{p}$.

Searcy, J. K., 1959, Flow-duration curves, in Manual of hydrology, part 2, low-flow techniques: U.S. Geological Survey Water-Supply Paper 1542-A $33 \mathrm{p}$.

Thomas, M. P., 1966, Effect of glacial geology upon the time distribution of streamflow in eastern and southern Connecticut: U.S. Geological Survey Professional Paper 550-B, p. B209-B212.

U.S. Environmental Protection Agency, 1975, Water programs, national interim primary drinkingwater regulations: Federal Register, v. 40, no. 248, Wednesday, December 24, 1975, part IV, p. 59566-59574.

1977, National secondary drinking water regulations: Federal Register, v. 42, no. 62, Thursday, March 31, 1977, part I, p. 1714317147.

1980, Interim primary drinking water regulations: Federal Register, v. 45, no. 168, Wednesday, August 27, 1980, p. 57332-57357.

1985, National primary drinking water regulations, volatile synthetic organic chemicals; Final rule and proposed rule: Federal Register, v. 50 , no. 219 , Wednesday, November 13 , part III, p. 46880-46933.

Wandle, S. W., Jr., and Keezer, G. R., 1984, Gazetteer of hydrologic characteristics of streams in Massachusetts--Taunton and Ten Mile River basins and coastal river basins of Mount Hope Bay, Narragansett Bay, and Rhode Island Sound: U.S. Geological Survey Water-Resources Investigations Report 84-4283, 38 p.
Willey, R. E., Williams, J. R., and Tasker, G. D., 1978, Water resources of the coastal drainage basins of southeastern Massachusetts, Westport River, Westport, to Seekonk: U.S. Geological Survey Hydrologic Investigations Atlas HA-275, scale 1:48,000.

Williams, J. R., 1968, Availability of ground water in the northern part Tenmile and Taunton River basins southeastern Massachusetts: U.S. Geological Survey Hydrologic Investigations Atlas HA-300, scale 1:48,000.

Williams, J. R., Farrell, D. F., and Willey, R. E., 1973, Water resources of the Taunton River basin, southeastern Massachusetts: U.S. Geological Survey Hydrologic Investigations Atlas HA-460, scale 1:48,000.

Williams, J. R., and Tasker, G. D., 1974, Water resources of the coastal drainage basins of southeastern Massachusetts, Plymouth to Weweantic River, Wareham: U.S. Geological Survey Hydrologic Investigations Atlas HA507, scale 1:48,000.

Williams, J. R., and Willey, R. E., 1967, Northern part Tenmile and Taunton River basins: U.S. Geological Survey Open-File Report, Massachusetts Basic-Data Report 10, Groundwater Series, $56 \mathrm{p}$.

1970, Taunton River basin: U.S. Geological Survey Open-File Report, Massachusetts Basic-Data Report 12, 102 p.

1973, Bedrock topography and texture of unconsolidated deposits, Taunton River basin, southeastern Massachusetts: U.S. Geological Survey Miscellaneous Investigations Map I-742, scale 1:48,000. 